\title{
Tourism Village Government Program, Characterized By State Defense as the Economic Foundation of National Defense
}

\author{
Kasih Prihantoro, Suhirwan, Anton Iman Santosa, Budi Pramono, Guntur Eko Saputro, Rianto, Lukman Yudho \\ Prakoso \\ Universitas Pertahanan Republik Indonesia \\ *Corresponding Author
}

\begin{abstract}
The Covid-19 pandemic has impacted the global, regional and national strategic environment. the economic sector is an area that is greatly affected as a whole. The current condition must immediately find an effective and efficient solution so that it does not become a more serious threat to the defense of the State. The method used in this paper is descriptive qualitative phenomenology using the theory of defense policy implementation by Lukman Yudho Prakoso which states that defense policy implementation can run well if you pay attention to the factors of Integrative, Interactive, Transparency, Controling and Accountability (IITCA). The results showed that the economic handling between the central and regional governments had not yet been integrated, interactive communication was still a major obstacle, with the arrest of the Minister of Social Affairs showing that there were still major problems related to transparency, controlling and accountability factors. The tourism village is one of the programs initiated by the government in the midst of the Covid-19 pandemic, which is expected to cause economic activity, especially in the field, so that this program is considered optimal as well to equip the state defense program for all parties involved, so that it is not vulnerable to being infiltrated by parties - irresponsible parties. The conclusion of this paper is in accordance with the theory of Kasih Prihantoro, so that the tourism village program with the character of defending the country as the foundation of the defense economy can run well, an effective and efficient netwok must be built and there must be a party acting as a driver force
\end{abstract}

Keywords: State Defense, Covid-19, Tourism Village, Defense Economy

\section{INTRODUCTION}

A fter the economic crisis in 1998, Indonesia experienced several more crises but not as great as during the pandemic. The impact of the Covid-19 pandemic has devastated the world economy, including Indonesia, which experienced a contraction in economic growth in 2020. At the global level, the impacts of climate change will also threaten the economy and the lives of the world community, including Indonesia. Climate change that occurs will cause the phenomenon of sea level rise and then cause seasonal or climate changes that are increasingly difficult to predict. All these dynamics will affect the Indonesian economy. If the government is unable to cope with the impact of the dynamics of these threats, the potential threat to State defense will be even stronger.

Economy and defense can be two sides of a coin that complement each other. This means that a strong defense requires good economic strength. Conversely, economic power needs security stability. So that the two cannot be separated. With the global, regional and national situation, the economic sector has become a highlight that must be addressed immediately considering that it supports the lives of many people related to the basic needs of society. One of the national programs initiated by the government is the Tourism Village Program which is expected to be a leveraging effect on the economy, especially for rural communities.

Indonesia as an archipelagic country has very broad access as well, so the possibility of crimes that interfere with Indonesia's domestic defense and security is very high. With the tourism village program, it can be an opportunity for these threats to infiltrate this program if the government does not proactively prepare everything to anticipate all possible threats that may arise.

In this article, the author will analyze how solutions to current economic problems can have a negative impact on national defense if solutions are not immediately sought. This paper will analyze from the perspective of defense economics. Defense economics is a study of resource allocation, income distribution, economic growth, and stabilization applied to topics related to defense (Hartlet et al, 1995).

\section{RESEARCH METHODS}

This research is a qualitative research using a library research approach, as stated by Zed (2004) who states that a library research is a research that utilizes literature sources to obtain research data, so that in this study the literature reference becomes the main source. The literature study in this research is carried out by searching and studying various literatures, scientific articles, both in the form of books, journals and other documents related to the development of tourism villages.

Sources of data in this study are books, journals, web pages and other references that are considered relevant to the theme 
in this study, namely examining the development of community-based tourism villages. Data analysis in this study was carried out through descriptive analysis method, which is defined as an attempt to collect and compile data, then an analysis of the data is carried out, while the data collected is in the form of words, pictures and not in the form of numbers (Surakhmad, 1990). In this case, the data regarding the development of the tourism village were collected from various sources and then the researcher carried out the analysis and interpretation of the data

\section{DISCUSSION}

Tourism Village is a community or community consisting of residents of a limited area who can interact with each other directly under a management and have the care and awareness to play a role together according to their respective skills and abilities to empower potential conducive to the growth and development of tourism and the realization of Sapta. Enchantment so as to achieve increased regional development through tourism and utilize it for the welfare of the people in the region.

Tourism Village is a self-help and community-driven group that in its social activities seeks to increase understanding of tourism, accommodate the role and participation of the community in tourism development in its territory, increase the value of tourism and empower it for the welfare of the community, participate in the success of tourism development

Tourism Village was formed to empower the community to be able to act as direct actors in an effort to increase readiness and awareness in addressing tourism potential or tourist attraction locations in their region so that they can act as good hosts for visiting tourists, and have an awareness of opportunities and opportunities. readiness to capture the benefits that can be developed from tourism activities to improve the economic welfare of the community.

The purpose of establishing a Tourism Village is to improve the position and role of the community as an important subject or actor in tourism development, and to synergize and partner with relevant stakeholders in improving the quality of tourism development in the region, building and fostering positive attitudes and support from the community as hosts through the realization Sapta Pesona values for the growth and development of tourism in the region and its benefits for regional development and community welfare and introducing, preserving and utilizing the potential tourist attractions that exist in each region.

The function of the Tourism Village is as a direct forum for the community to be aware of the potential for tourism and the creation of Sapta Pesona in the regional environment in tourist destinations and as an element of partnership both for the provincial government and regional (district / city) governments in an effort to realize and develop tourism in the regions.
Defense economy comes from two important words which have their respective meanings, namely economy and defense. There are salient conceptual differences between economy and defense. The main difference lies in the character of the two concepts, namely, the economy prioritizes "sovereignty lies in unlimited human needs", while the character of defense is "sovereignty is in the hands of the state". This has a consequence: "If it is agreed to eliminate economic activity it means negating human nature, and if it eliminates defense activities it means negating the presence of the state". Because it is necessary to connect the two different characters so that they are closely related and complementary (Makmur Keliat, 2010)

To see the economy and defense, it is necessary to look at their respective concepts, both of which aim to achieve social welfare. The welfare of a country can be increased through high economic growth. However, the government will be able to implement various programs that can stimulate growth if the country's conditions are safe. Thus, to improve welfare, the government is also obliged to realize national security. National security is a condition or condition that describes the freedom of the state, society and citizens from all forms of threats and / or actions, whether influenced by external or internal factors. National security can also be interpreted as the need to maintain and maintain the existence of the state through economic, military and political strength and the development of diplomacy. (Secretariat General of the National Resilience Council, 2010)

Development and efforts to find solutions in the midst of the Covid-19 Pandemic must also consider other factors, especially those related to defense and security. Thus, the development being carried out must also be able to create a sense of security and comfort among individuals and groups in carrying out their activities so that they can increase their utility to the maximum. To create a sense of security, defense is needed to eliminate threats faced by a country. State protection that is given to all nations and all spills is interpreted as security protection for all citizens and all territories and all the resources in them.

The current form of threats to state sovereignty is increasingly multidimensional in line with the development of advances in science, technology, information and communication. Therefore, the entire Indonesian nation is required to be able to overcome every threat, challenge, obstacle and disturbance, both coming from within and outside the country.

Regarding the tourism village program, this requires an understanding of the importance of awareness of defending the country. And this requires the active participation of all Indonesians so that we can protect the sovereignty of the Unitary State of the Republic of Indonesia (NKRI). The awareness of defending the state has a strong legal basis, namely the 1945 Constitution article 27 paragraph 3, which states that "Every citizen has the right and obligation to participate in efforts to defend the state" and Article 30 
paragraph (1) mandates that " citizens have the right and obligation to participate in the affairs of state defense and security "

To carry out the mandate of the 1945 Constitution, it is deemed necessary to translate it into concrete programs or activities to all levels of society. The obligation to defend the state is not only carried out by the military, but can be carried out by those who are not military, especially to face nonmilitary threats such as threats without weapons that have the ability to endanger or have implications for threatening the country's sovereignty, the territorial integrity of the state and the safety of the entire nation.

The Tourism Village Program and its relation to defending the country, it is clear that defending the country is important to be instilled as a foundation for the attitudes and behavior of the Indonesian nation. At the same time, to build the nation's resilience in facing the complexities of threat dynamics in order to realize national resilience. State defense is also the nation's social capital to build itself into a more advanced, personable and cultured nation that is equal to other developed countries in world civilization.

In the future, an effective state defense concept and program is needed, so that all citizens can participate in programs implemented by both government agencies and the state defense community. Therefore, state defense education is mandatory. This is in line with the currently developing empirical reality, namely when it is related to the empirical condition of Indonesia which is at the intersection of world interests. This empirical reality is what Indonesia needs to reorient its national defense system. In addition, there are future interests, particularly in relation to potential threats in the future.

The Tourism Village Program and its relation to the development of national character through fostering awareness and ability to defend the state for every Indonesian citizen is very important. For this reason, it is necessary to prepare Human Resources (HR) in the framework of national defense, as well as strengthening the national identity with a personality and culture based on Pancasila and the 1945 Constitution of the Republic of Indonesia.

Fostering awareness and ability to defend the state in the tourism village program at least prepares people with national insight, character and integrity so that they can contribute to the progress and integrity of the Republic of Indonesia. The preparation of reliable human resources certainly has an impact on the quality of mindset and positive actions in managing national resources to maintain the survival of the nation and state. So that with the awareness of building a good country it will raise a collective spirit to achieve Indonesia's glory.

Because it is time for the name of Indonesia to become more fragrant and have higher dignity, with world-class achievements in various fields, participate in various noble activities, and collaborate with other nations in creating world security and peace. Collective spirit and an attitude of innovation need to be intensified in order to create inventions. new findings by Indonesians. So that other countries will judge Indonesia as a nation that has competitiveness. Maybe this is part of the real action of a state defense program.

In the field of tourism, with the tourism village program, for example, the state defense program can also be carried out in a massive and sustainable way, including by fostering farmers and other village communities in the villages to be able to compete with foreign products. State defense cadres can provide marketing assistance to farmers for their agricultural products. This is important to do, considering that currently the onslaught of imports into our beloved country is so fierce.

The following are the results of data collection on what happened to the tourism village program that needs to be found a solution through a combination with the State Defense program:

Weak Human Resources: Human Resources are quite a challenge in developing tourist villages, this is because human resources are the caretakers who determine everything related to tourism and tourism villages. In the hands of managers with competent resources, the tourism village will undoubtedly be able to run and grow progressively, but on the other hand, in the hands of the lack of human resources, the tourism village will run in place or even go out of business.

Therefore, in the development of a tourist village, it is very concerned with the professionalism of human resources, both in investment management or in the fields of accommodation, transportation, communication and information.

The existence of competent human resources is also in other tourism-related sectors, for example those who set up restaurants near tourist villages, those who sell or produce handicrafts, therefore there needs to be an understanding and sufficient knowledge so that they can work together. build a developed tourist village.

If the existing tourism village is managed by low human resources, it is possible that the tourism sector will be controlled by investors outside the village who have better human resources and are more prepared in terms of capital. Of course this has its pluses and minuses, but it would be much better if the overall management could be carried out by local village human resources.

It is feared that tourism activities will destroy local cultural values. Tourism village activities that are rich in customs, cultural attractions and full of traditional elements are indeed a distinct value and become an attraction for tourist visits, but this is also considered to be damaging to the value of the village's local culture.

As an illustration, there is a shift in the value of traditional ceremonies which can lead to commercialization for the purpose of being "sold" as a tourist show. This condition is 
certainly not completely like this, therefore this challenge needs to be resolved properly, namely so that the noble values of local culture are well preserved even though they are wrapped in tourism village activities.

Inadequate Information System: The information system is an important part of the continuation of tourist visits, both foreign and local, why is that? Because the nature of information is often misunderstood, for example when there was a riot in Jakarta, people or potential foreign tourists thought that all of Indonesia was not safe and there was a riot.

Therefore it is necessary to have an adequate information system that provides the latest updates and is able to provide information that the location of tourist visits is safe to visit. This is especially true for natural tourism destinations such as adjacent to an active volcano, so the information system about mountain activities must be completely updated and can be conveyed to the wider community.

The existence of this information system is to provide clarification, as well as to proactively prepare and provide information about tourist objects, readiness of facilities, infrastructure and others. Information about the route to the location, facilities at the site of the visit and complete information about tourist visiting areas need to be conveyed with a good and right-on-target information system.

Media Coverage on Indonesian Security; We cannot deny that Indonesia's security from the threat of terrorism is still a consideration when foreign tourists decide to travel to Indonesia. The track record of terrorism and riots in Indonesia is still frequent, and this becomes one of the obstacles for foreign tourists to Indonesia.

For example, the case of terrorism that occurred in Sarinah, Jakarta some time ago, this incident was successfully handled by the Indonesian security forces, however, for governments of other countries, this incident remains a precaution. So they issue a warning for their citizens who visit Indonesia, this of course affects the Indonesian tourism market.

Indonesia's security condition is a challenge for Indonesia and all of us in order to create absolute security, so that tourists both from within and outside the country feel safe. And creating security is our common duty.

By paying attention to the problems of the existing tourism village program using the theory of defense policy implementation Lukman Yudho Prakoso, who said that defense policy implementation can run well if he considers Integrative, Interactive, Transparency, Controlling and Accountability (IITCA) factors. So it appears that there has been no program integration between the Ministry of Tourism and other related ministries and institutions, for example to ward off the threat of ideology that could infiltrate this tourism village program, the tourism ministry should be able to involve the Perthanan Ministry to simultaneously implement a negative program against rural communities become the target of the tourism village program. The current condition also shows that the interactive communication conditions have not yet occurred.

Regarding the issue of transparency, control and accountability systems in general are still homework for every sector of ministries and institutions currently in Indonesia. In the midst of the economic crisis due to the Covid-19 pandemic, there are still government officials who have been arrested for corruption; this is all because of the still weak budget transparency system, bureaucratic control system and accountability for activities which continue to be problems for which there is no solution.

Problems as described above are mainly related to concerns about threats in maintaining the existing culture and threats to security and security stability, so this paper provides a solution like what is conveyed by Kasih Prihantoro (2019) that:

Build the right Networking. In government policy programs related to the many entities involved in it, the use of a network topology or network topology determines the effectiveness and efficiency of the implementation of policy implementation.

The need for Driver Force: A government program that involves many different entities from Ministries and Institutions requires one entity that can act as a driver force so that there is a unity of motion and decisions so that effective and efficient program implementation activities can be achieved.

\section{CONCLUSION}

The development of a tourism village is a form of rural development policy that tries to diversify villages which have been based mostly on agriculture. Tourism villages are developed to become villages based on the tourism industry, both service businesses and commercial businesses in the form of tourism products. In its development, a tourism village is a process of extracting the potential that exists in the village whether it comes from natural, social, cultural, community or other elements, so that the natural and sustainable characteristics of the village are maintained and preserved.

The economic factor that became a problem during the Covid19 pandemic received a breath of fresh air with the existence of the tourism village program, however the need to consider possible threats that could infiltrate besides the program, so that it becomes a solution to the program with a combination of the state defense program from the ministry of defense, so it is hoped that there is immunity to the community against the possibility of an infiltrating threat. The tourism village program involves several ministries and institutions so that it is deemed necessary to build a network and the existence of a driver force so that this tourism village program can be implemented effectively and efficiently. 


\section{REFERENCES}

[1] Ali, I. M., Prakoso, L. Y., \& Sianturi, D. (2021). Strategi Pertahanan Laut dalam Menghadapi Ancaman Keamanan maritim di Wilayah Laut Indonesia. Strategi Pertahanan Laut, 6(2), 169188.

[2] Arto, R. S., Prakoso, L. Y., \& Sianturi, D. (2019). Strategi Pertahanan Laut Indonesia dalam Perspektif Maritim Menghadapi Globalisasi. Strategi Pertahanan Laut, 5(2), 65-86.

[3] Dipua, A., Hermawan, R., Puspitawati, D., Harahap, N., Rizanny, D., \& Prakoso, L. Y. (2020). An Analysis of The South China Sea Conflict: Indonesia's Perspectives, Contexts and Recomendations. PalArch's Journal of Archaeology of Egypt/Egyptology, 17(4), 976-990.

[4] Guntur Eko Saputro, L. Y. (2021). Implementation of Economic Policies Facing Covid 19 in Supporting Nonmilitary Defense. International Journal of Social Science And Human Research, 634-642.

[5] Harris, A., Prakoso, L. Y., \& Sianturi, D. (2019).Strategi Pertahanan Laut dalam Rangka Ancaman Keamanan di Alur Laut Kepulauan Indonesia II. Strategi Pertahanan Laut, 5(1), 15-30.

[6] Hermawan, T., Prakoso, L. Y., \& Sianturi, D. (2020).Strategi Pertahanan Laut dalam Analisa Dampak dan Upaya Pemerintah Mengamankan ALur Laut Kepulauan Indonesia. Strategi Pertahanan Laut, 6(3), 273-296.

[7] Kurniawan, C., Widyarto, S., \& Prakoso, L. Y. (2018).Implementasi Struktur Birokrasi Strategi Pertahanan Laut Menghadapi Ancaman di Perairan Provinsi Sulawesi Tenggara. Strategi Pertahanan Laut, 4(1), 1-18.

[8] Kusuma, A. W., Prakoso, L. Y., \& Sianturi, D. (2019).Sinergitas Komando Armada I dan Badan Keamanan Laut Republik Indonesia dalam Strategi Pertahanan Laut Guna Memberantas Kejahatan Lintas Negara di Selat Malaka. Strategi Pertahanan Laut, 5(2), 51-64.

[9] Hartley, Keith dan Sandler, Todd (1995).Handbook of Defense Economics, Volume 1. Elsevier Science. Hal 6.

[10] Keliat, Makmur. (2010)Ekonomi Pertahanan Indonesia. Prisma Majalah Pemikiran Sosial Ekonomi Vol.29 No.1

[11] Listiyono, Y., Prakoso, L. Y., \& Sianturi, D. (2019b). Strategi Pertahanan Laut dalam Pengamanan Alur Laut Kepulauan Indonesia untuk Mewujudkan Keamanan Maritim dan Mempertahankan Kedaulatan Indonesia. Strategi Pertahanan Laut, 5(3), 103-116.

[12] Lebo, D., Pramono, B., Prakoso, L. Y., Risman, H., \& Akrimi, N. (2021, April 6). The Total War Strategy through Optimizing the Understanding of Pancasila Values in the Millenial Era. https://doi.org/10.31014/aior.1991.04.02.273

[13] Madrohim, M., \& Prakoso, L. Y. (2021). The Total War Strategy Through the Improvement of the Role of National Shipyard in
Supporting Main Weapon System of Indonesian Navy. Journal of Social and Political Sciences, 4(1). https://doi.org/10.31014/aior.1991.04.01.245

[14] Palupi, E., S., DAR, D., Suhardono, E., Sianturi, D., Prakoso, L. Y., \& Bangun, E. (2021, March 26). Sea Defense Strategy Strengthening Through Improving The Readiness of Indonesian Naval Vessel Crew (Study: The Health Office of 1st Fleet Command) E. https://doi.org/10.31014/aior.1991.04.01.266

[15] Prakoso, Lukman Yudho, \& Aprilliyani, R. (2021). Implementasi Ilmu Teknik Elektro Bidang Pertahanan dan Militer (K. Prihantoro \& S. Suhirwan (eds.); 1st ed.). CV. Aksara Global Akademia.

[16] Prakoso, Lukman Yudho, Suhirwan, \& Prihantoro, K. (2020).Sea Defense Strategy and Urgency of Forming Maritime Command Center. Jurnal Pertahanan, 6(2), 200-211. https://doi.org/http://dx.doi.org/10.33172/jp.v6i2

[17] Surakhmad, W., 1990. Pengantar Penelitian Ilmiah. Bandung: Tarsito.

[18] Sekretariat Jendral Dewan Ketahanan Nasional (2010)

[19] Sartono, Prakoso, L. Y., \& Sianturi, D. (2020). Impresi dan Otoritas Pemerintah dalam Mengamankan Alur Laut Kepulauan Indonesia (ALKI). Strategi Pertahanan Laut, 6(3), 231-256.

[20] Sartono, Prakoso, L. Y., \& Suseto, B. (2019). Perimbangan Kekuatan Laut Indonesia Masa Kini Dihadapkan dengan Geopolitik Kawasan Asia Pasifik. Strategi Pertahanan Laut, 5(2), 87-114.

[21] Suhirwan, \& Prakoso, L. Y. (2019a). Defense strategy at sea handling of Transnational Organized Crime (TNOC) in Nunukan Indonesia's national sea border. IOP Conference Series: Earth and Environmental Science, 339, 12043. https://doi.org/10.1088/17551315/339/1/012043

[22] Suhirwan, \& Prakoso, L. Y. (2019b). Forum Maritim Kunci Sukses Penanggulangan Ancaman Asimetris di Selat Sunda. Seminar Dan Lokakarya Kualitatif Indonesia 2019, 2019, 2019.

[23] Suhirwan, Prodjonoto, K. W. A., \& Prakoso, L. Y. (2020). Archipelago State Strategic Ocean Tracker (1st ed.). CV. Nas Media Pustaka.

[24] Supriyono, Prakoso, L. Y., \& Sianturi, D. (2019). Pentingnya Penanaman Nilai-Nilai Kebangsaan bagi Masyarakat Pesisir Pulau Terdepan sebagai Upaya Keikutsertaan Warga Negara dalam Bela Negara. Strategi Pertahanan Laut, 5(3), 117-132.

[25] Widiarto, S., S., Prakoso, L. Y., S., Suhardono, E., Warka, I. W., \& D.A.R, D. (2021, March 17). Optimization of Sea Defense Strategy Through Operation of the Hospital Auxiliary Vessel to Support National Defense. https://doi.org/10.31014/aior.1991.04.01.262

[26] Zed, M., 2004. Metode Penelitian Kepustakaan. Jakarta: Yayasan Obor Indonesia 